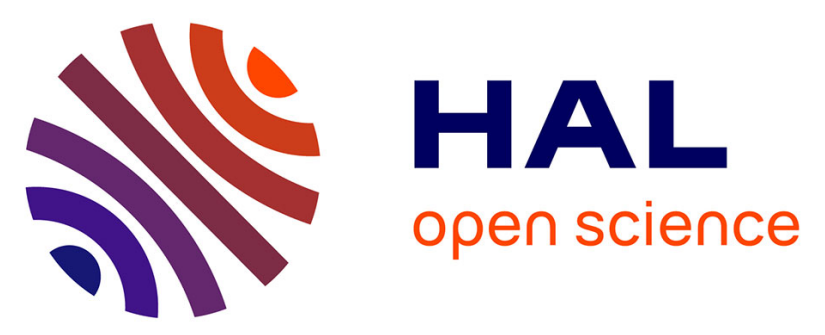

\title{
Radiation-induced reductions in transporter mRNA levels parallel reductions in intestinal sugar transport
}

Marjolaine Roche, Prasad V. S. V. Neti, Francis W Kemp, Amit Agrawal, Alicia Attanasio, Véronique Douard, Anjali Muduli, Edouard I Azzam, Edward Norkus, Michael Brimacombe, et al.

\section{To cite this version:}

Marjolaine Roche, Prasad V. S. V. Neti, Francis W Kemp, Amit Agrawal, Alicia Attanasio, et al.. Radiation-induced reductions in transporter mRNA levels parallel reductions in intestinal sugar transport. AJP - Regulatory, Integrative and Comparative Physiology, 2010, 298 (1), pp.R173-R182. 10.1152/ajpregu.00612.2009 . hal-01602292

\section{HAL Id: hal-01602292 https://hal.science/hal-01602292}

Submitted on 31 May 2020

HAL is a multi-disciplinary open access archive for the deposit and dissemination of scientific research documents, whether they are published or not. The documents may come from teaching and research institutions in France or abroad, or from public or private research centers.
L'archive ouverte pluridisciplinaire HAL, est destinée au dépôt et à la diffusion de documents scientifiques de niveau recherche, publiés ou non, émanant des établissements d'enseignement et de recherche français ou étrangers, des laboratoires publics ou privés.

$$
\text { Copyright }
$$




\title{
Radiation-induced reductions in transporter mRNA levels parallel reductions
}

\section{in intestinal sugar transport}

\author{
Marjolaine Roche, ${ }^{1}$ Prasad V. S. V. Neti, ${ }^{2}$ Francis W. Kemp, ${ }^{3}$ Amit Agrawal, ${ }^{1}$ Alicia Attanasio, ${ }^{1}$ \\ Véronique Douard, ${ }^{1}$ Anjali Muduli, ${ }^{1}$ Edouard I. Azzam, ${ }^{2}$ Edward Norkus, ${ }^{4}$ Michael Brimacombe, ${ }^{3}$ \\ Roger W. Howell, ${ }^{2}$ and Ronaldo P. Ferraris ${ }^{1}$ \\ ${ }^{1}$ Department of Pharmacology and Physiology, New Jersey Medical School; ${ }^{2}$ Department of Radiology, New Jersey Medical \\ School Cancer Center; and ${ }^{3}$ Department of Preventive Medicine and Community Health, New Jersey Medical School, \\ University of Medicine and Dentistry of New Jersey, Newark, New Jersey; and ${ }^{4}$ Our Lady of Mercy Medical Center, \\ Brooklyn, New York
}

Submitted 25 September 2009; accepted in final form 10 November 2009

Roche M, Neti PVSV, Kemp FW, Agrawal A, Attanasio A, Douard V, Muduli A, Azzam EI, Norkus E, Brimacombe M, Howell RW, Ferraris RP. Radiation-induced reductions in transporter mRNA levels parallel reductions in intestinal sugar transport. Am J Physiol Regul Integr Comp Physiol 298: R173-R182, 2010. First published November 11, 2009; doi:10.1152/ajpregu.00612.2009.--More than a century ago, ionizing radiation was observed to damage the radiosensitive small intestine. Although a large number of studies has since shown that radiation reduces rates of intestinal digestion and absorption of nutrients, no study has determined whether radiation affects mRNA expression and dietary regulation of nutrient transporters. Since radiation generates free radicals and disrupts DNA replication, we tested the hypotheses that at doses known to reduce sugar absorption, radiation decreases the mRNA abundance of sugar transporters SGLT1 and GLUT5, prevents substrate regulation of sugar transporter expression, and causes reductions in sugar absorption that can be prevented by consumption of the antioxidant vitamin A, previously shown by us to radioprotect the testes. Mice were acutely irradiated with ${ }^{137} \mathrm{Cs}$ gamma rays at doses of $0,7,8.5$, or $10 \mathrm{~Gy}$ over the whole body. Mice were fed with vitamin A-supplemented diet $(100 \times$ the control diet) for 5 days prior to irradiation after which the diet was continued until death. Intestinal sugar transport was studied at days 2, 5 , 8 , and 14 postirradiation. By day 8 , D-glucose uptake decreased by $\sim 10-20 \%$ and D-fructose uptake by $25-85 \%$. With increasing radiation dose, the quantity of heterogeneous nuclear RNA increased for both transporters, whereas mRNA levels decreased, paralleling reductions in transport. Enterocytes of mice fed the vitamin A supplement had $\geq 6$-fold retinol concentrations than those of mice fed control diets, confirming considerable intestinal vitamin A uptake. However, vitamin A supplementation had no effect on clinical or transport parameters and afforded no protection against radiation-induced changes in intestinal sugar transport. Radiation markedly reduced GLUT5 activity and mRNA abundance, but high-D-fructose diets enhanced GLUT5 activity and mRNA expression in both unirradiated and irradiated mice. In conclusion, the effect of radiation may be posttranscriptional, and radiation-damaged intestines can still respond to dietary stimuli.

dietary regulation; GLUT5; oxidative stress; SGLT1; vitamin A absorption

THE FIRST REPORT OF radiation-induced damage of the intestine was in 1897 (50) just two years after the discovery of X-rays by Roentgen. Decades later, in 1931 came the initial reports about the direct detrimental effects of ionizing radiation on

Address for reprint requests and other correspondence: R. P. Ferraris, Dept. of Pharmacology and Physiology, UMDNJ-New Jersey Medical School, 185 S. Orange Ave., Newark, NJ 07101-1709 (e-mail: ferraris@umdnj.edu). intestinal nutrient transport, followed thereafter by numerous reports that intestinal transport of D-glucose is generally affected by acute irradiation $(3,7,11)$. Almost nothing is known about the effect of radiation on transport of the other major dietary sugar, D-fructose. Despite the large number of studies demonstrating mainly detrimental effects of radiation on absorptive function, there has not been a single study monitoring mRNA expression of intestinal transporters after radiation. This is unfortunate, because exposure to ionizing radiation causes cellular injury in the gut due, in part, from the increased production of free radicals and oxidative stress $(25,40)$, which, in turn, can interfere with DNA replication and gene expression. It is therefore highly likely that the mechanisms underlying radiation-induced damage to the radiosensitive small intestine include processes involving gene transcription and translation.

Nutrient transport is an essential function of the small intestine and must be retained even after radiation-induced damage. DGlucose is transported across the apical membrane by the $\mathrm{Na}^{+}$dependent glucose transporter SGLT1 into the cytosol. D-Fructose, the sugar found mainly in honey and fruits, is transported across the apical membrane by GLUT5. The transport of Dglucose by SGLT1 is active and therefore energy dependent (27). In contrast, GLUT5 facilitates passive transport of D-fructose (9, 13). Consumption of dietary glucose increases SGLT1 expression and activity $(15,31)$, while consumption of dietary fructose increases GLUT5 expression and activity $(20,29)$.

The potential of antioxidant nutrients to reduce the cellular damage induced by ionizing radiation has been studied in animal models for $>50 \mathrm{yr}$ (51). Some antioxidant vitamins have been shown to decrease radiation-induced oxidative stress (18). Among them is vitamin A, which has afforded protection against radiation-induced cellular damage in rat lungs (41), guinea pig neutrophils (4), and mouse testes (23, 24). As a critical micronutrient, vitamin $\mathrm{A}$ is essential for vision, maintenance of skin, and mucosal integrity, and spermatogenesis (2, 45). The main dietary forms of vitamin A are retinyl esters, which are hydrolyzed in the lumen to free retinol by retinyl ester hydrolases (42). The cellular retinol binding protein II, expressed specifically in the rodent small intestine, seems to facilitate intestinal absorption and metabolism of retinol (17).

The aim of the present study was to investigate in mice the response of the two main sugar transporters, GLUT5 and SGLT1, after acute whole body irradiation with low linear energy transfer (LET) gamma rays. Uptake studies were undertaken to quantify the transport of D-fructose and D-glucose 
into the small intestinal cells and to correlate changes in rates of transport with measurements of heterogeneous nuclear (hnRNA) and mRNA expression of SGLT1 and GLUT5. Additional uptake studies were undertaken to assess, for the first time, whether radiation interferes with the upregulation of SGLT1 or GLUT5 expression with high D-glucose or D-fructose diets, respectively. The capacity of vitamin A to protect against radiation-induced reductions in transport of these sugars was also investigated.

\section{MATERIALS AND METHODS}

\section{Radiochemicals}

D-Glucose and D-fructose were purchased from Sigma and Mallinckrodt (St. Louis, MO), respectively. D- $\left[{ }^{14} \mathrm{C}\right]$ glucose $(31 \mathrm{MBq} /$ $\mathrm{ml} ; 0.85 \mathrm{mCi} / \mathrm{ml})$ and $\mathrm{L}-\left[{ }^{3} \mathrm{H}\right]$ glucose $(37 \mathrm{MBq} / \mathrm{ml})$, were purchased from Sigma, D- $\left[{ }^{14} \mathrm{C}\right]$ fructose $(19 \mathrm{MBq} / \mathrm{ml})$ was from ARC (St. Louis, $\mathrm{MO})$, and $\left[{ }^{14} \mathrm{C}\right]$ inulin-carboxyl $(19 \mathrm{MBq} / \mathrm{ml})$ was from Perkin-Elmer (Waltham, MA).

\section{Animals}

Swiss Webster adult male mice, 30-45 g, 7-8 wk of age, were purchased from Taconic Farms, Germantown, NY. The experiments were conducted under a protocol approved by the Institutional Animal Care and Use Committee, University of Medicine and Dentistry of New Jersey and New Jersey Medical School, Newark, NJ.

\section{Experimental Design of Vitamin A Diet Study}

The study was divided into three separate but identical trials with 64 mice per trial. Data from all trials were combined. In each trial, mice were housed two per cage, in a sterilized, filtered, positive air-flow cage with feed and water provided ad libitum. Cage facilities were maintained in a climate-controlled room with 12:12-h light-dark cycles in the Comparative Medicine Resource Center at the New Jersey Medical School, University Hospital Cancer Center. Mice were weighed the day after arrival, stratified by weight, and then randomly assigned to 1 of 8 study groups. A $2 \times 4$ factorial experimental design was used with two diets and four radiation-absorbed doses. The randomization resulted in overall diet/dose mean body weights ranging from 35.2-35.8 $\mathrm{g}$ with $n=24 \mathrm{per}$ diet/dose group. Each diet/dose group was again randomly selected for tissue harvest on either day 2, 5 , 8 , or 14 postirradiation. The study diets were pelleted AIN-76A rodent diet (control) or a modified AIN-76A rodent diet supplemented with $400 \mathrm{IU} / \mathrm{g}$ retinol acetate (vitamin A, 100× the control diet) (Research Diets, New Brunswick, NJ). All mice were acclimated for 3 days to the laboratory environment and the control rodent diet. Following the 3-day acclimation period, the vitamin A-enriched diet was substituted for the control diet for mice in the vitamin A study group (Fig. 1A). This change provided a 5-day preirradiation ingestion of the retinol supplement. Absorbed doses (referred to in the remainder of the manuscript as "dose") of 7, 8.5, or 10 Gy were delivered acutely with a Mark I ${ }^{137} \mathrm{Cs}$-irradiator (661 keV gamma rays) operating at a dose rate of $1.14 \mathrm{~Gy} / \mathrm{min}$ (JL Shepherd, San Fernando, CA) to the entire body of unanesthetized, free-moving mice $(37,38)$. Mark I Irradiators irradiated the mice on turntables adjacent to a line source of $\mathrm{Cs}^{137}$. Mice on both control and vitamin A diets were placed in segmented circular $(\sim 30 \mathrm{~cm}$ diameter) trays that rotated in the isodose zone. The absorbed doses were calibrated using a Radcal monitor model 9010 (Radcal, Monrovia, CA) radiation dosimeter probes. Sham irradiated mice $(0 \mathrm{~Gy})$ were placed in the irradiator for the time equivalent to the maximum ${ }^{137} \mathrm{Cs}$ source exposure period without activating the source. Mouse weight and diet consumption were monitored prior to and after irradiation. As detailed below, on predetermined days postirradiation, animals were killed and the small intestine was removed for analysis.
A

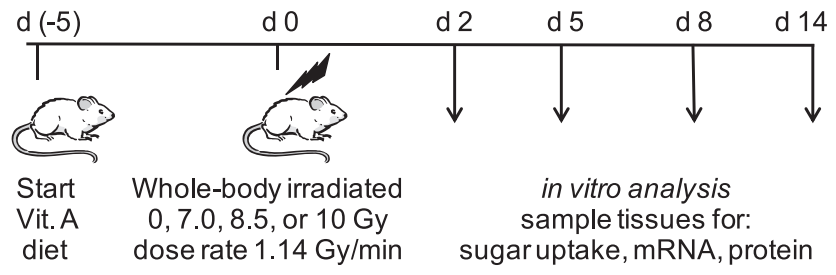

B

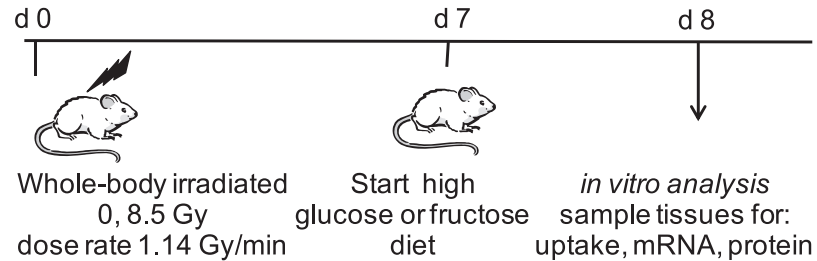

Fig. 1. Design of the 2 experiments where mice were acutely irradiated with low linear energy transfer (LET) gamma rays and fed specific diets: vitamin A-enriched diet $(A)$ or high-sugar (D-fructose or D-glucose) diets $(B)$. Arrows, postirradiation days when mice were killed; d, day.

\section{Experimental Design of D-Fructose and D-Glucose Loading- Diet Studies}

A similar study was undertaken using the AIN-93M D-fructose modified diet (high D-fructose) containing $630 \mathrm{~g}$ D-fructose $/ \mathrm{kg}$ of diet, while a second diet was prepared that contained $630 \mathrm{~g}$ D-glucose $/ \mathrm{kg}$ (high D-glucose) (Research Diets, New Brunswick, NJ). Mice of 11 wk of age were acutely irradiated with 0 or 8.5 Gy as described above. Mice were fed the control diet ad libitum prior to and for 7 days postirradiation, whereupon the AIN-93M sugar-modified diets were substituted for $24 \mathrm{~h}$ prior to death (total 8 days of postirradiation). The small intestine was removed for further biochemical and histological studies (Fig. 1B)

\section{Animal Surgery}

The small intestine was surgically removed on days $2,5,8$, or 14 postirradiation. Mice were anesthetized by intraperitoneally injecting a $5 \mathrm{ml} / \mathrm{kg}$ of mouse body wt anesthesia cocktail containing $5.8 \mathrm{ml}$ ketamine (stock: $100 \mathrm{mg} / \mathrm{ml}), 2.9 \mathrm{ml}$ xylazine $(20 \mathrm{mg} / \mathrm{ml}), 1.3 \mathrm{ml}$ acepromazine $(10 \mathrm{mg} / \mathrm{ml})$, and $50 \mathrm{ml}$ sterile water. The intestine was subsequently perfused and conserved in an ice-cold Krebs Ringer bicarbonate solution (KRB1 buffer in mmol/l: $128 \mathrm{NaCl}, 4.7 \mathrm{KCl}, 2.5$ $\mathrm{CaCl}_{2} \cdot 5 \mathrm{H}_{2} \mathrm{O}, 1.2 \mathrm{MgSO}_{4}, 19 \mathrm{NaHCO}_{3}$, and $1.2 \mathrm{KH}_{2} \mathrm{PO}_{4}, \mathrm{pH} 7.3-7.4$ ) and immediately processed for sugar uptake and other measurements. After excision of the small intestine, the mouse was killed by intracardiac injection of $0.2 \mathrm{ml}$ euthanol (Virbac, Fort Worth, TX).

\section{Histology}

Mouse jejunum was fixed in fresh $4 \%$ paraformaldehyde in PBS $(\mathrm{pH} 7.35)$ overnight at room temperature and then embedded in paraffin. Sections of $5 \mu \mathrm{m}$ were stained with hematoxylin and eosin with an Automat Autostainer XL (Leica Microsystem, Bannockburn, IL). Examinations of villi were performed at $\times 100$ magnification with a BX60 microscope (Olympus, Melville, NY). All images were captured using a SPOT RT-SE color digital camera, and SPOT imaging software was used for image acquisition and processing (Diagnostics Instruments, Sterling Heights, MI).

\section{Intestinal Uptake of D-Glucose, D-Fructose, and L-Glucose}

D-Glucose, D-fructose, and L-glucose uptake rates were determined as described earlier $(20,30)$. Briefly, several $1-\mathrm{cm}$ segments of the 
proximal jejunum were individually mounted and everted on grooved steel rods (3-mm diameter). Rods with the everted tissue segment (sleeve) were preincubated at $37^{\circ} \mathrm{C}$ for $5 \mathrm{~min}$ in a $\mathrm{KRB} 1$ buffer bubbled with $95 \% \quad \mathrm{O}_{2}-5 \% \quad \mathrm{CO}_{2}$. For D-glucose uptake, the tissue segment was incubated at $37^{\circ} \mathrm{C}$ for $1 \mathrm{~min}$ in a freshly made oxygenated solution of KRB2 buffer (KRB1 buffer plus $103 \mathrm{mmol} / \mathrm{l} \mathrm{NaCl}$ instead of 128) containing $50 \mathrm{mmol} / \mathrm{l}$ of D-glucose, $380 \mu \mathrm{mol} / \mathrm{l}$ of $\mathrm{D}-\left[{ }^{14} \mathrm{C}\right]$-glucose $(0.8 \mu \mathrm{Ci} / \mathrm{ml})$, and $0.2 \mu \mathrm{mol} / 1$ of $\mathrm{L}-\left[{ }^{3} \mathrm{H}\right]$-glucose $(0.9$ $\mu \mathrm{Ci} / \mathrm{ml})$. Similarly, D-fructose uptake was measured after 2-min incubation in an oxygenated solution of KRB2 buffer containing 50 $\mathrm{mmol} / \mathrm{l}$ of $\mathrm{D}$-fructose, $1.6 \mu \mathrm{mol} / \mathrm{l}$ of $\mathrm{D}-\left[{ }^{14} \mathrm{C}\right]$-fructose $(0.5 \mu \mathrm{Ci} / \mathrm{ml})$, and $0.2 \mu \mathrm{mol} / \mathrm{l}$ of $\mathrm{L}-\left[{ }^{3} \mathrm{H}\right]$-glucose $(0.9 \mu \mathrm{Ci} / \mathrm{ml})$. L- $\left[{ }^{3} \mathrm{H}\right]$-glucose was used to correct for adherent fluid and passive diffusion of D-glucose or D-fructose. Finally, sleeves were washed for $20 \mathrm{~s}$ in a cold KRB1 buffer with stirring. L-Glucose uptake was measured after $5 \mathrm{~min}$ incubation in an oxygenated solution of KRB1 buffer containing 0.1 $\mu \mathrm{mol} / \mathrm{l}$ of L- $\left[{ }^{3} \mathrm{H}\right]$-glucose $(0.9 \mu \mathrm{Ci} / \mathrm{ml})$ and $20 \mu \mathrm{m}\left[{ }^{14} \mathrm{C}\right]$-inulin $(0.25$ $\mu \mathrm{Ci} / \mathrm{ml})$.

Wet weight of each $1-\mathrm{cm}$ piece of intestine was obtained after transferring to a preweighed vial and then dissolved in $1 \mathrm{ml}$ of Solvable (Perkin Elmer, Boston, CA) at $37^{\circ} \mathrm{C}$ for $18 \mathrm{~h}$ or at ambient temperature for $48 \mathrm{~h}$. Following dissolution, a $10 \mathrm{ml}$ volume of Ecolume (MP Biomedicals, Irvine, CA) was added to each vial and then vortexed and incubated for a minimum of $24 \mathrm{~h}$. The ${ }^{3} \mathrm{H}$ and ${ }^{14} \mathrm{C}$ activities per segment were determined by dual-label counting with a manually calibrated LS 6500 Liquid Scintillation Counter (Beckman Coulter, Fullerton, CA). Quench curves were created using the LS 6500 software and counting samples with a range of tissue weights, each spiked with the same activity of ${ }^{3} \mathrm{H},{ }^{14} \mathrm{C}$, or a combination of ${ }^{3} \mathrm{H}$ and ${ }^{14} \mathrm{C}$-labeled sugar. Sugar uptakes were calculated as described earlier $(20,30)$ and expressed as nanomoles of sugar per minute per centimeter or per milligram of wet weight of intestine.

\section{Intestinal Absorption of Vitamin A}

In a separate study, mice were fed the vitamin A-enriched diet as per Fig. 1A. Tissue concentrations for retinol and retinyl esters in the small intestine were determined to assess the effect of a vitamin A diet on mucosal retinoid concentrations compared with mice on the control diet. Intestines were harvested as described above, and one-halfcentimeter sections of the proximal jejunum and the distal ileum were cut, weighed, flash frozen in liquid nitrogen, and stored at $-80^{\circ} \mathrm{C}$. The amount of free retinol and retinyl esters in the tissues were quantified by HPLC (47).

\section{RNA Analysis}

Total RNA. At $10 \mathrm{~cm}$ from the proximal end of the small intestine, a $2-\mathrm{cm}$ piece was excised, scraped to remove muscle tissue, immediately frozen in liquid nitrogen, and stored at $-80^{\circ} \mathrm{C}$. Total RNA was extracted with Trizol (Invitrogen, Carlsbad, CA) according to the manufacturer's recommendations and quantified with a spectrophotometer. The isolated RNA was subjected to an RT-PCR using an iCycler thermal cycler (Bio-Rad, Hercules, CA) with the SuperScript III Reverse Transcriptase kit (Invitrogen) according to the manufacturer's instructions. The cDNA obtained was subjected to real-time PCR for the GLUT5, SGLT1, and $\beta$-actin (housekeeping gene) genes using the Mx3000P QPCR System (Stratagene, La Jolla, CA). The real-time PCR was performed using Brilliant SYBR Green QPCR Master Mix Reagent (Stratagene). Thermal cycling proceeded with 40 cycles (initial activation step: $10 \mathrm{~min}$ at $95^{\circ} \mathrm{C} ; 40$ cycles: $30 \mathrm{~s}$ at $95^{\circ} \mathrm{C}$; $1 \mathrm{~min}$ annealing temperature of primers: $30 \mathrm{~s}$ at $72^{\circ} \mathrm{C}$; and terminal step: $1 \mathrm{~min}$ at $95^{\circ} \mathrm{C}$ and $30 \mathrm{~s}$ at $55^{\circ} \mathrm{C}$ ). The amount of RNA was calculated with relative standard curves for RNA of the specific genes studied. Normalization to $\beta$-actin was conducted to account for variability in concentration of total RNA (5). Preliminary work showed that irradiation did not affect $\beta$-actin mRNA levels (not shown). To examine for genomic contamination, the reaction was also carried out in samples that did not receive reverse transcriptase amplification reagents.

hnRNA. Since ionizing radiation at doses used in this study are likely to affect mainly gene replication and transcription, we determined levels of hnRNA, the first product of transcription that includes both introns and exons, and mRNA (described below). A DNase I and RNeasy miniprotocol (Qiagen, Valencia, CA) was carried out on total RNA to remove DNA and thereby ensure no genomic DNA amplification. Purified total RNA was reverse transcribed with the reverse primer that was annealed to a sequence within an intron to amplify only the hnRNA. Real-time PCRs were then performed with the following primers: GLUT5 (forward: 5'-TAC AAC GTA GCT GCC GTC AAC TCT-3', reverse: 5'-AAG CTG TGT TTG TTC TCT GGG GAC-3'); SGLT1 (forward: 5'-GGC TGA CAT CTC AGT CAT CGT CAT-3', reverse“ " 5'-GGG ATA TCT CCA CTG TAA GCC CAT-3'); $\beta$-actin (forward: $5^{\prime}$ - TTC TTT GCA GCT CCT TCG TTG CCG-3', reverse: 5'-TCT ACA CGC TAG GCG TAA AGT TGG-3'). The forward primers were designed to correspond to the exonic sequence and were contained within the exon, and the reverse primers were designed to correspond to the intronic sequence and were contained within the intron.

$m R N A$. An RT-PCR was then carried out on total RNA, followed by real-time PCR with the following primer sequences: GLUT5 (forward: 5'-TGC AGA GCA ACG ATG GAG AAA-3', reverse: 5'-ACA GCA GCG TCA GGG TGA AG no base missing-3'); SGLT1 (forward: 5'-GAA GCT ACT GCC CAT GTT CCT CAT-3', reverse: $5^{\prime}$-ACT GGT GTG CCG CAG TAT TTC TGA-3'); $\beta$-actin (forward: 5' -TTG TTA CCA ACT GGG ACG ACA TGG-3', reverse: 5'-CTG GGG TGT TGA AGG TCT CAA ACA-3'). These primers were designed to amplify only the mRNAs.

\section{Statistics}

Uptake values were expressed as means \pm SE unless otherwise stated. The number of mice used in the present study is denoted by $n$. One-way ANOVA (dose or diet or duration effects), two-way ANOVA (dose and diet, dose and duration, or diet and duration effects) or General linear models analysis for unbalanced data was used to determine the statistical significance of differences (considered significant if $P<0.05$ ). Pairwise differences were evaluated subsequent to two-way ANOVA or general linear models data by comparison of least square means. Statistical evaluations were performed using StatView software (version 5; Abacus Concepts, Berkeley, CA) or SAS (Statistical Analysis Systems, Cary, NC).

\section{RESULTS}

\section{Diet Consumption of Vitamin A Supplemented and Control Diets}

There were no significant differences in consumption of the control and vitamin A diets during the 5-day period prior to irradiation ( $\sim 5 \mathrm{~g} /$ day per mouse). Mice not exposed to radiation had similar intakes of both diets, suggesting that vitamin A does not affect feeding rate. At days 2, 5, and 8 postirradiation, diet consumption showed no or small $(<10 \%)$ diet-dependent reductions.

\section{Body Weights and Mortality Rates of Mice Fed with Control and Vitamin A Diets}

There were no significant differences related to diet/dose group assignments for body weights during the acclimation, preirradiation, irradiation, and the 2-day postirradiation periods (average $\sim 38 \mathrm{~g}$ ). Small $(\sim 10 \%)$ dose-dependent body weight differences were observed at days 5 and 8 postirradiation. Unirradiated mice, all mice irradiated with $7 \mathrm{~Gy}$, and almost all 
mice irradiated with 8.5 and 10 Gy survived 8 days postirradiation. However, most mice in the 10-Gy group died by 14-day postirradiation. In summary, irradiation with gamma rays had modest effects on feeding rate, body weight, and mortality rate, especially at doses $\leq 8.5$ Gy and at postirradiation times $<8$ days. Since we were examining acute effects in vivo of radiation on sugar transporters, we focused on uptakes obtained at $\leq 8$ days.

\section{Intestinal Weights and Mucosal Morphology}

The uptake method required the weight measurement of 1 $\mathrm{cm}$ of intestine and allowed determinations of the influence of radiation on intestinal weight per centimeter and total intestinal weight (Table 1). Radiation dose and diet had no significant effect on tissue weight per centimeter at any day postirradiation (except day 14) and on total intestinal weight at days 2 and 5 postirradiation. Total intestinal weight varied with dose only on day $8(P=0.02)$, and irradiation affected only intestinal weight in mice exposed to $10 \mathrm{~Gy}$. Day 14 samples were not analyzed since there were insufficient numbers of mice that survived the 8.5 and 10 Gy doses.

Hematoxylin and eosin staining of the proximal jejunum showed that the macro-structure of the villi at 8 days postirradiation appeared intact and that there were no instances of shedding of villus cells or of villi sections devoid of enterocytes (Fig. 2). These confirm Table 1 results, indicating modest changes in tissue weight per centimeter and intestinal weight of mice irradiated at $8.5 \mathrm{~Gy}$ dose, to 8 days postirradiation.

\section{Vitamin A Absorption}

After 5 days of diet consumption, analysis of mouse proximal jejunal tissue showed a dramatic increase in the concentrations of retinol and four major retinyl esters for mice fed with the vitamin A supplemented diet (Fig. 3A). Analysis of the intestinal mucosa found a combination of retinol and retinol esters of four different fatty acids $(n=9)$ : palmitate $(\mathrm{C} 16: 0)$, stearate (C18:0), oleate (C18:1), and linoleate (C18:2). In the plasma, retinoid concentrations were much greater in mice fed the vitamin A supplement, and the major retinoid components were found to be retinol, retinyl palmitate, and retinyl stearate (Fig. 3B).

\section{Sugar Uptake of Mice Fed with Control or Vitamin A Diet}

When analyzed by three-way ANOVA, there is no diet effect on any D-fructose or D-glucose uptake rates at any time
$(P=0.3-0.8)$, hence we pooled uptakes from vitamin A and control mice and then analyzed these pooled uptakes by twoway ANOVA for the effect of radiation dose and postirradiation day (up to day 8). Pooled D-fructose uptake per centimeter (Fig. 4, $A-C)$ was strongly affected by radiation dose $(P<$ $0.0001)$ and not by postirradiation day $(P=0.14)$. There was a highly significant interaction between dose and postirradiation day $(P<0.0001)$, suggesting that the effect of dose depended on time postirradiation. Uptake rates on day 14 were excluded because of missing numbers of mice (Fig. 4, $D$ and $H$ ). Pooled D-fructose uptake per milligram (Fig. $4, E-G$ ) was strongly affected by radiation dose $(P<0.0001)$ and modestly by postirradiation day $(P=0.02)$. Interaction between dose and postirradiation day was again highly significant at $P=$ 0.0001. Compared with unirradiated controls, the effect of dose on pooled D-fructose uptake per centimeter and per milligram was greatest at day 8 postirradiation $(P<0.0001)$ when uptake rates declined by up to $\sim 85 \%$ at 10 Gy and $\sim 25 \%$ at 8.5 and $7 \mathrm{~Gy}$. The effect of dose was modest at day 5 postirradiation.

Pooled D-glucose uptake per centimeter decreased with postirradiation day $(P<0.01)$ but not with radiation dose $(P=$ $0.5)$; interaction was not significant $(P=0.6)$ (Fig. 5, $A-C)$. At 5 and 8 days postirradiation, uptake per centimeter decreased by up to $\sim 25 \%$ for mice exposed to 8.5 and $10 \mathrm{~Gy}$. Uptake rates on day 14 were not analyzed because of missing numbers of mice (Fig. 5, $D$ and $H$ ). D-Glucose uptake per milligram decreased with postirradiation day $(P<0.0001)$ but not with radiation dose $(P=0.6)$; interaction was not significant $(P=$ 0.6) (Fig. 5, $E-G$ ). Compared with unirradiated controls, pooled D-glucose uptake per milligram decreased by up to $35 \%$ at 5 days postirradiation with 8.5 and $10 \mathrm{~Gy}$. The decrease was smaller $(\sim 15 \%)$ at 8 days postirradiation with 8.5 and $10 \mathrm{~Gy}$.

\section{L-Glucose Uptake}

There was no significant effect of radiation on L-glucose uptake at 8 days postirradiation: for $0 \mathrm{~Gy}, 21.5 \pm 4.1 \mathrm{fmol} / \mathrm{mg}$ $\mathrm{min}$; for $8.5 \mathrm{~Gy}, 18.3 \pm 1.7 \mathrm{fmol} / \mathrm{mg} \mathrm{min}$; and for $10 \mathrm{~Gy}$, $23.3 \pm 4.2 \mathrm{fmol} / \mathrm{mg} \min (P=0.73)$. Experiments using other doses, postirradiation times, and chronic irradiation for $72 \mathrm{~h}$ with doses up to 14.4 Gy also had no effect on L-glucose uptake (M. Roche, F. W. Kemp, P. V. S. V. Neti, R. W. Howell, R. P. Ferris, unpublished observations). Absence of significant uptake of L-glucose indicates that the integrity of the intestinal barrier is maintained.

Table 1. Weight of one centimeter of everted small intestine and total intestinal weight as a function of vitamin A supplementation, radiation dose, and days postirradiation

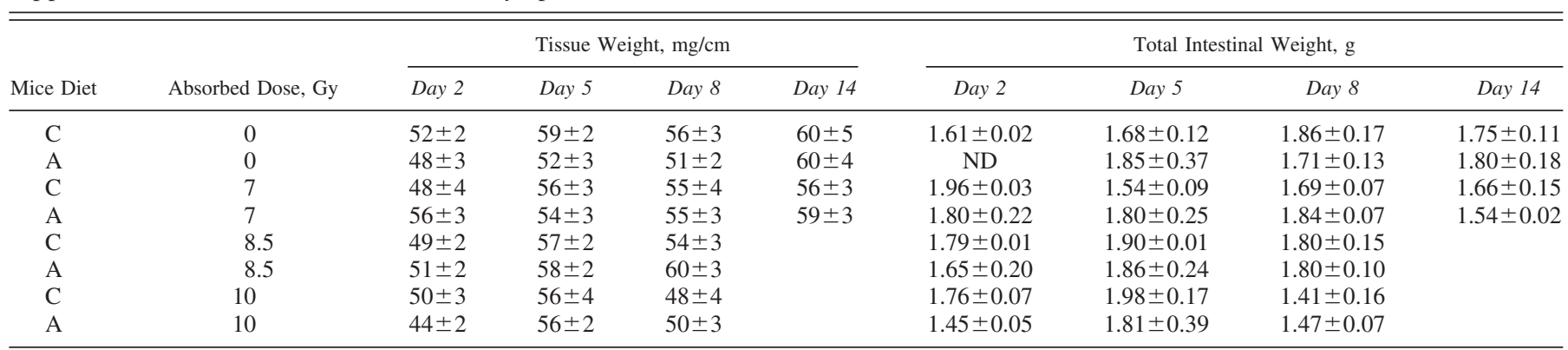

Values are means \pm SE of 6 independent experiments explained in Fig. 1A. C, control diet containing vitamin A at normal levels; A, diet supplemented with vitamin A; ND, not determined. There was no significant effect of vitamin supplementation and of radiation dose by two-way ANOVA. 

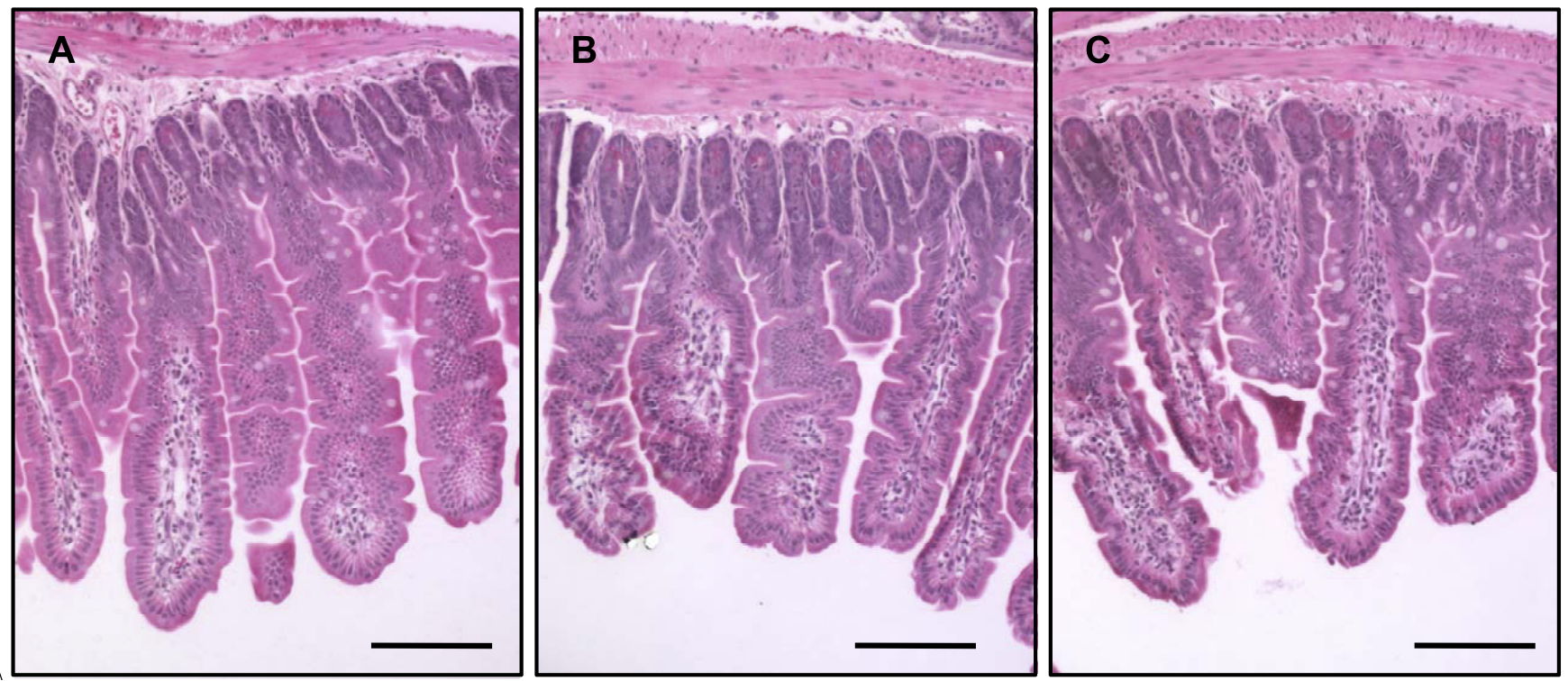

Fig. 2. Light micrograph of a cross section (hematoxylin and eosin stained) of proximal jejunum of mice fed with control diet and killed at day 8 postirradiation: 0 Gy $(A), 8.5 \mathrm{~Gy}(B)$, and $10 \mathrm{~Gy}(C)$. Bars are $75 \mu \mathrm{m}$. Villi were intact in unirradiated and irradiated mice, independent of diet. Mice irradiated with 7 Gy and mice consuming vitamin A-supplemented diet not shown.

\section{hnRNA and mRNA Levels of Sugar Transporters in Intestinal Mucosa of Mice Fed Control Diet}

In Figs. $6, A$ and $B$, RNA quantification by real-time PCR showed significant $(P<0.05)$ radiation-induced increases of

\section{A}

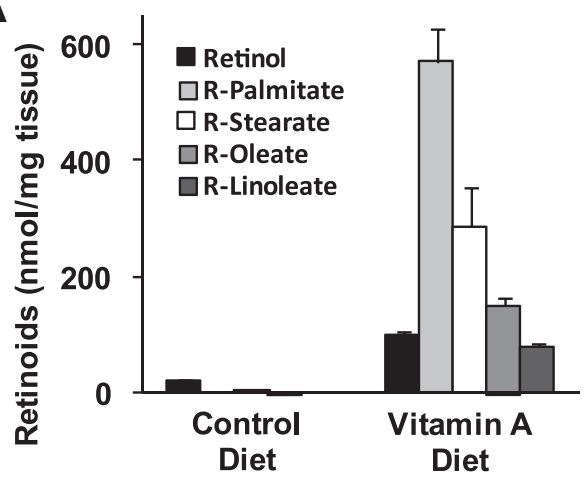

B

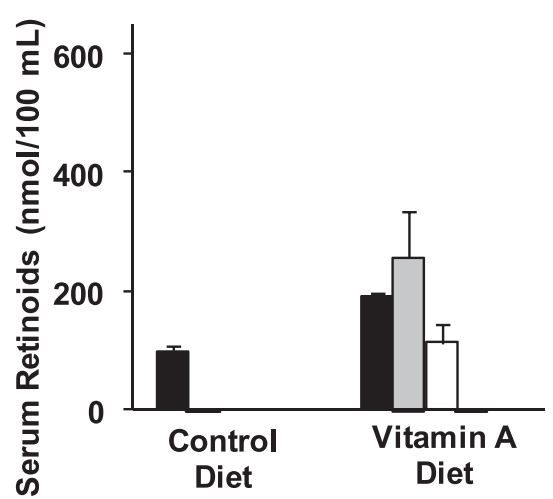

Fig. 3. Retinoid concentrations in mouse proximal jejunum $(A)$ and serum $(B)$ after 5 days of the vitamin A-enriched diet or the control diet. Results are means \pm $\mathrm{SE}$ ( $n=6$ for $A ; n=3$ for $B$ ). Clearly, a much greater amount of vitamin A was absorbed and retained in mice fed vitamin A-supplemented diets.
SGLT1 and GLUT5 hnRNA levels. In contrast, mRNA levels of both transporters decreased $(P<0.05)$ when mice were irradiated (GLUT5 by about threefold, SGLT1 by twofold). The coefficient of variation might have been high because GLUT5 expression and activity tended to be low if intestines were not exposed to daily D-fructose.

\section{Transporter mRNA Levels in Mice Fed High D-Fructose and D-Glucose Diets}

The decrease in transporter mRNA levels and transport rates following irradiation was confirmed in a separate experiment using well-known methods to induce increases in GLUT5 mRNA and activity by dietary D-fructose. Moreover, if we observed classical diet-induced increases in levels of GLUT5 mRNA and in rates of D-fructose uptake at the same time as radiation-induced decreases, it would confirm the latter. Control mice (0 Gy) and mice acutely irradiated with 8.5 Gy were fed a D-glucose- or D-fructose-enriched diet on day 7 postirradiation (Fig. 1B). Mice were killed, and sugar uptakes were measured on the 8th day postirradiation (Fig. 7). By two-way ANOVA, there were significant dose $(P=0.0034)$ and diet $(P<0.0001)$ effects on D-fructose uptake per centimeter [uptake per milligram had almost exactly the same patterns (not shown)]. There was no significant interaction between dose and diet $(P=0.74)$. Compared with mice fed high D-glucose, the high-D-fructose diet enhanced the uptake of D-fructose (Fig. 7A) (32) by twofold in both the unirradiated and irradiated mice. However, mice irradiated with 8.5 Gy had significantly lower rates of intestinal D-fructose uptake than unirradiated mice (Fig. 7A) in groups fed either the high-Dfructose $(P=0.02)$ or the high-D-glucose $(P=0.07)$ diet. D-glucose uptake did not change after $24 \mathrm{~h}$ consumption of the D-fructose or D-glucose diet (Fig. $7 B$ ). In fact, D-glucose uptake was independent of dose $(P=0.46)$ and diet $(P=0.29$ by two-way ANOVA). This finding does not contradict regulation of SGLT1 by its substrate glucose (15) as previously mentioned. Since SGLT1 can also be regulated by luminal galactose, fructose, 


\section{D-fructose uptake}

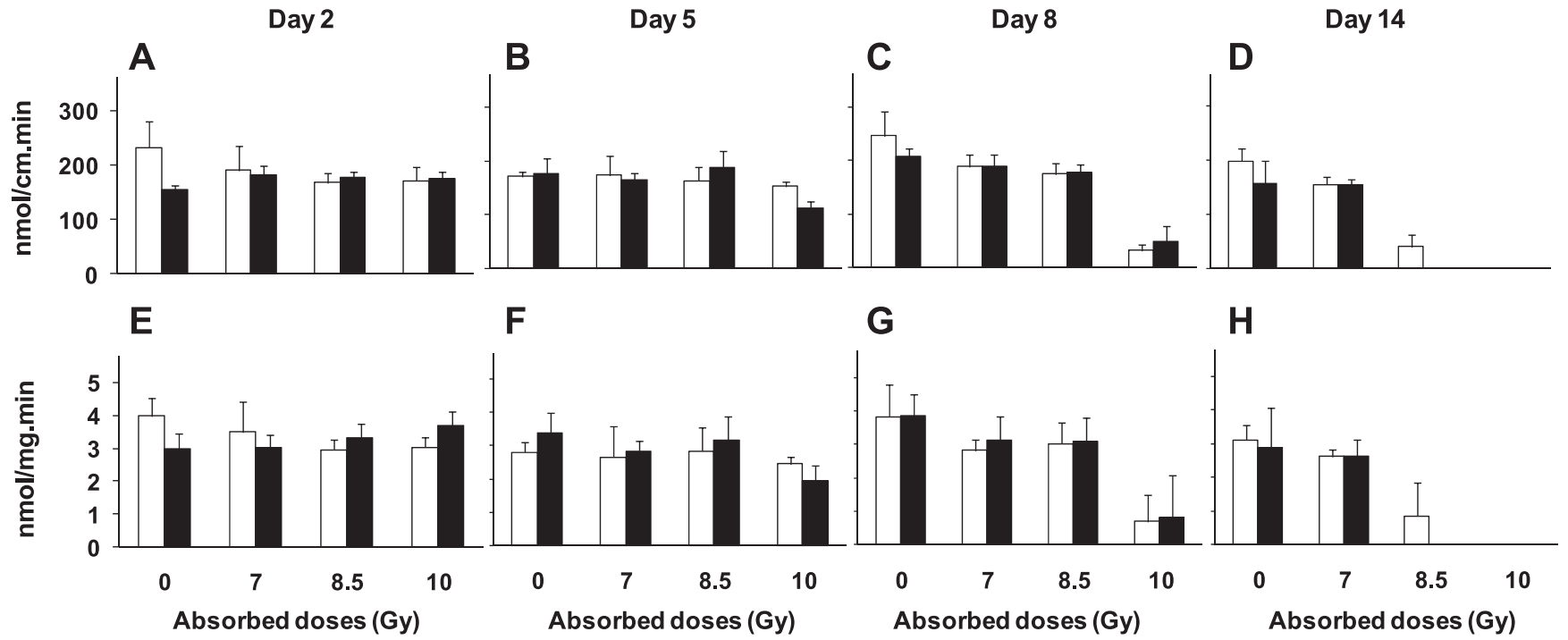

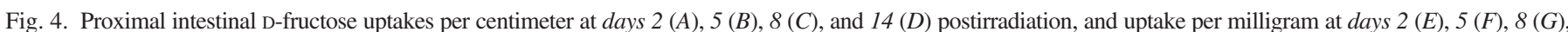

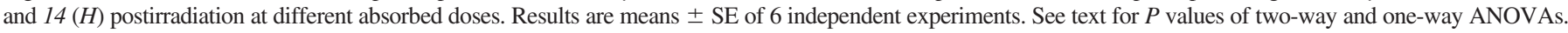
Similar per centimeter and per milligram results suggest that reductions were likely due to decreased transporters per cell and not to decreases in number of cells.

and even some nonmetabolizable analogs of glucose (44), it would not be possible to detect diet-induced changes in SGLT1 activity because we were comparing high-glucose and highfructose diets. In contrast, GLUT5 is specifically regulated by fructose $(10,44)$.

The relative GLUT5 mRNA abundance was much higher in animals that received the high-D-fructose diet compared with those that received the D-glucose diet (Fig. $7 C$ ). For both unirradiated and irradiated mice, D-fructose increased GLUT5 mRNA by $>10$-fold. The effect of radiation dose was not significant $(P=0.16)$, primarily because relative GLUT5 expression was already low in mice fed D-glucose and there was no radiationinduced decrease in this group. In contrast, there was a significant radiation-induced, two-fold decrease of the GLUT5 mRNA abundance in 8.5 Gy-irradiated mice fed fructose (Fig. 7C) $(P=0.04)$ that we could not observe for mice fed the D-glucose diet. The relative SGLT1 mRNA abundance did not vary with diet $(P=$ $0.16)$ and radiation dose ( $P=0.11$ by two-way ANOVA). There was a tendency for SGLT1 mRNA abundance to decrease with radiation dose in mice given the high-D-fructose diet $(P=0.08)$ but not for mice given the high-D-glucose diet (Fig. 7D).

\section{DISCUSSION}

There are three main findings in this study. First, while there have been numerous studies on the effects of ionizing radiation

\section{D-glucose uptake}

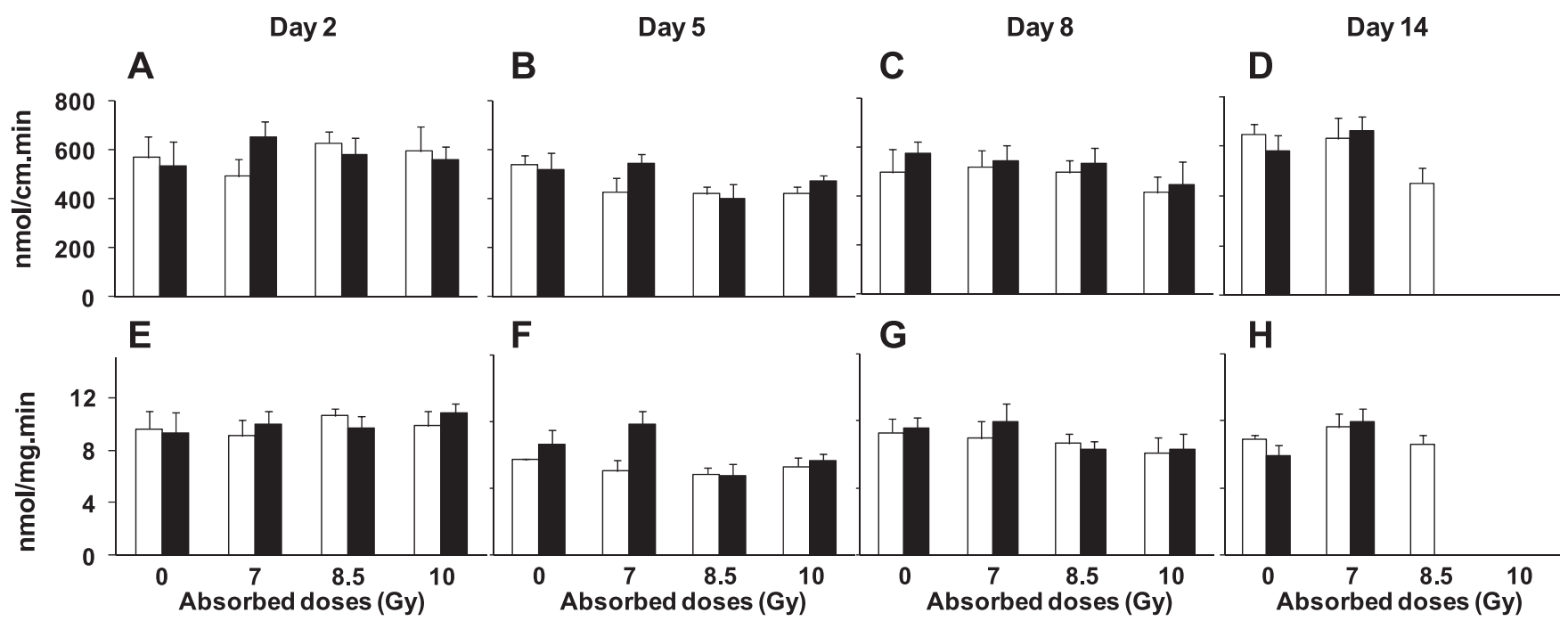

Fig. 5. Proximal intestinal D-glucose uptakes per centimeter at days $2(A), 5(B), 8(C)$, and $14(D)$ postirradiation and uptake per milligram at days $2(E), 5(F)$, $8(G)$, and $14(H)$ postirradiation at different absorbed doses. Results are means \pm SE of 6 independent experiments. See text for $P$ values of two-way and one-way ANOVAs. There were similar trends in radiation-induced reductions of D-glucose uptake per centimeter and per milligram. 
A

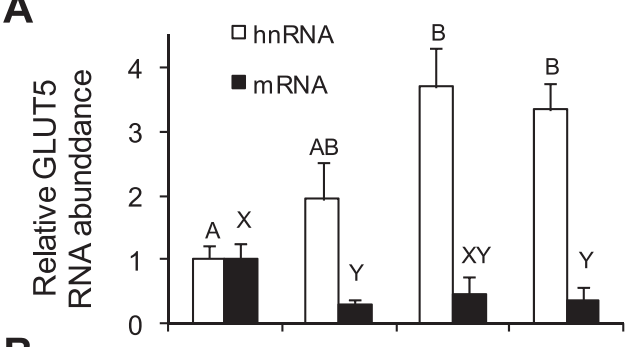

B

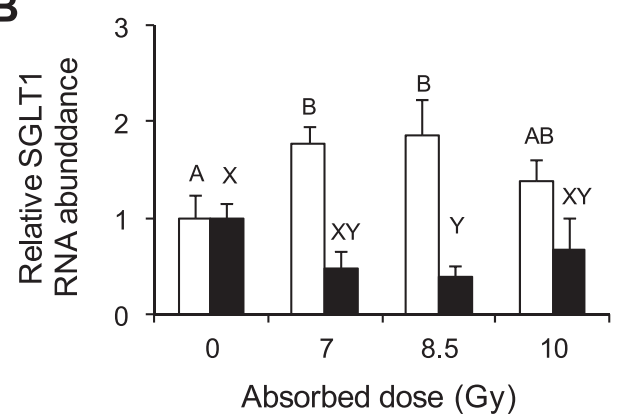

Fig. 6. Effect of gamma rays on relative (to $0 \mathrm{~Gy}$ ) heterogeneous nuclear (hnRNA) and mRNA abundance of GLUT5 $(A)$ and SGLT1 $(B)$ measured by real-time PCR in mice fed with the control diet and killed 8 days postirradiation. Results are means \pm SE $(n=6)$. Bars with different letters are significantly different $(P<0.05)$. See text for $P$ values. Levels of transporter hnRNA increase, while levels of transporter mRNA decrease with increasing radiation dose.

on sugar transport, we report here for the first time that steady-state levels of sugar transporter mRNA are also likely reduced by ionizing radiation and may explain, in part, radiation-induced reductions in transporter activity. Second, radiation-damaged intestines retain the capacity to remodel transporter site density in response to dietary signals, suggesting that the factors involved in dietary regulation of sugar transporters are retained. Third, a surprising finding has been that sugar transporters have different sensitivities to ionizing radiation, with GLUT5 being more sensitive than SGLT1. Other interesting findings are 1 ) that consumption of high levels of vitamin A increases levels of vitamin A metabolites in intestinal tissue and in the blood but does not prevent radiationinduced reductions in fructose transport, and 2) that reductions in sugar transport occur days after the radiation insult.

\section{Radiation-Induced Reductions in Sugar Transport}

In humans, radiation injury significantly increases the risk of chronic diarrhea and sugar malabsorption by $40 \%(33,35)$. These findings have been confirmed in animal models. In mice whose upper abdomens were irradiated, in vivo D-glucose absorption decreased within 4-5 days with increasing radiation dose (5-17.5 Gy); absorption was normal after 1 wk (39). A study of rats X-irradiated and subsequently intestinally perfused with D-fructose, D-glucose, and D-xylose showed a slight decrease in absorption of all three sugars (8). Likewise, in vitro active uptake in rats decreased within 3 days after a 6-Gy dose but returned to normal after 7 days (3). Other studies utilizing lower doses or assessments of uptake at long times postirradiation were less conclusive $(11,48,49)$. One confounding difficulty associated with these studies and ours has been the inability to distinguish radiation-induced reductions in intrinsic transport efficiency and transporter density per enterocyte from

radiation-induced reductions in number of enterocytes per centimeter of intestine. In the small intestine, there is a marked decrease, within hours of postirradiation, in the proliferative activity of undifferentiated crypt cells, followed by a dramatic increase in proliferative activity days and weeks postirradiation (6). Undifferentiated, dividing cells at the time of irradiation are likely damaged so that decreases in absorption are observed days after the radiation insult as these damaged cells migrate upward and populate the villus. However, it is only at highradiation doses that the number of cells entering the villus from the crypt becomes insufficient to maintain the enterocyte population and consequently leads to decrease in villus heights. For example, localized irradiation of rat intestinal segments with 18,21 , or 29.6 Gy resulted in epithelial denudation followed by mucosal ulceration and by intestinal fibrosis (21). At these doses, all types of nutrient transport would decrease. To avoid these complications, we used lower doses in our preliminary (1 and 5 Gy; V. Douard, A. Muduli, R. W. Howell, R. P. Ferraris, unpublished data) and present studies (7, 8.5, and $10 \mathrm{~Gy}$ ), and we measured uptake on postirradiation days when the mucosa was still intact, even at doses (e.g., $10 \mathrm{~Gy}$ ) that may eventually lead to mucosal alterations at a later date. In fact, by 14 days postirradiation, weight per centimeter intestine of some mice exposed to 8.5 Gy has already decreased by $\sim 25 \%$ (data not shown), suggesting loss of mucosa so often observed in radiation poisoning $(21,33)$.

Fructose transport was clearly reduced before overt decreases in mucosal weight and changes in mucosal appearance.
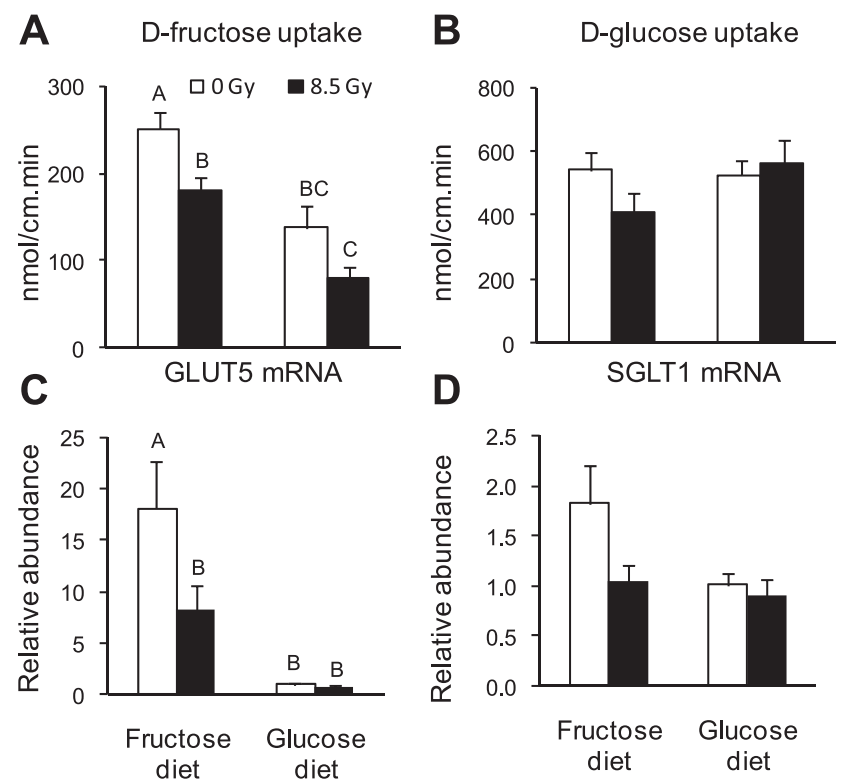

Fig. 7. Effect of irradiation on rates of intestinal sugar uptake and on relative mRNA abundance of the sugars transporters of mice fed with high-sugar diets (experimental design in Fig. $1 B$ ). D-Fructose uptake $(A)$ and D-glucose uptake $(B)$ per centimeter at 8 days postirradiation at the proximal part of the small intestine of mice acutely gamma-irradiated at $0 \mathrm{~Gy}$ and $8.5 \mathrm{~Gy}$. Mice were fed with $60 \%$ D-fructose or $60 \%$ D-glucose diet for $24 \mathrm{~h}$ (start specific diet at 7 days postirradiation), then killed. Relative (to D-glucose diet at 0 Gy) mRNA abundance of GLUT5 $(C)$ and SGLT1 $(D)$ is shown. Results are means \pm SE $(n=6)$. Bars with different letters are significantly different $(P<0.05)$. See text for $P$ values. D-Fructose uptake rate and GLUT5 mRNA abundance increase in both irradiated and unirradiated mice fed a D-fructose diet. DFructose uptake rate and GLUT5 mRNA abundance decreased markedly in irradiated mice fed D-fructose. 
In fact, the weight of the $1-\mathrm{cm}$ proximal jejunum sections and of total intestinal weight did not decrease, and intact intestinal villi were still observed up to 8 days postirradiation. Therefore, the reduction of D-fructose uptake was not likely to be due to a decrease in the number of enterocytes per centimeter but rather to a decrease either in the efficiency of D-fructose transporters or the number of transporters per enterocyte. Decreases in transporter efficiency and/or number per enterocyte would result in parallel reductions in D-fructose absorption per centimeter and per milligram, as shown in RESULTS. Finally, these findings on radiation-induced reductions in D-fructose transport per milligram are supported not only by independent experiments on the effect of radiation on diet-induced increases in D-fructose transport rate but also by specific decreases in GLUT5 mRNA.

Reductions in D-fructose absorption could not be due to changes in permeability of the mucosa to sugars, as L-glucose uptake did not change with radiation dose. Uptake of L-glucose and D-leucine (isomer of L-leucine not recognized by any known amino acid transport system) did not change 3-14 days after rat abdominal irradiation with 6 Gy (3).

\section{Parallel Reductions in Sugar Transporter mRNA and Activity}

Changes in levels of hnRNA that are processed in the nucleus are opposite those for transporter activity, but changes in levels of mRNA processed in the cytosol (36) parallel those for transporter activity, suggesting that posttranscriptional processing or stability of mRNA in the cytosol may be more radiosensitive compared with transcriptional processes in the nucleus. Ionizing radiation interacts with cellular constituents, mainly water molecules, to produce reactive oxygen species (12), inducing significant oxidative stress in cells. Posttranscriptional changes in several families of mRNAs are regulated specifically by reactive oxygen species (1), and regulation is carried out by specific turnover and translation of regulatory mRNA-binding (TTR-RBP) proteins that control the level of response of gene expression to oxidative damage. It is possible that GLUT5 and SGLT1 are some of the target genes regulated by TTR-RBP, and that their posttranscriptional processing is sensitive to oxidative stress, explaining in part, lower rates of sugar transport after irradiation. Moreover, we (14) and others $(15,16)$ have previously found rates of intestinal sugar transport to be directly proportional to levels of transporter proteins in the brush-border membrane. Future studies on the effect of radiation on transcription and stability of transporter mRNA and on translation of transporter protein should yield additional mechanistic information about the effect of radiation on intestinal sugar transport.

\section{Comparison Between Passive D-Fructose and Active D-Glucose Transport}

Since active transport involves more complex mechanisms than passive transport, we predicted that active transporters would be more radiosensitive than passive. However, there is a large difference between radiation-induced changes in passive transport of D-fructose and active transport of D-glucose, with the former being much more radiosensitive. Two independent studies were used to reach this conclusion: the experiments using high-sugar diets and the experiments evaluating the radioprotective potential of vitamin A. In these latter experiments, D-glucose transport did not decrease until days 8 and 14 , with reductions by day 14 likely due to mucosal injury. The complex mechanisms underlying the different response of GLUT5 and SGLT1 to radiation are not clear and require further study. The possibility that damage to the basolateral sugar transporter GLUT2 may result in reductions in fructose, and glucose transport is unlikely because of differences in the time course of radiation-induced damage to fructose and glucose transport and because the everted sleeve method determines primarily uptake via the apical membrane.

\section{Vitamin A Effect}

Since low-LET gamma radiation predominantly damages intestinal cells indirectly by generating excessive levels of reactive oxygen species, we used the antioxidant vitamin A as a potential radioprotector of these intestinal cells, since we found this vitamin an effective radioprotector of testicular cells (24). Unfortunately, vitamin A did not significantly protect intestinal nutrient transport against radiation damage, even though proximal jejunal cells and the serum had high levels of incorporated vitamin A. It is possible that oxidative stress in irradiated, vitamin A-fed mice may have been exacerbated, as an increase in retinoid levels can increase levels of intracellular reactive oxygen species, generating more damage than protection $(22,23)$. However, others have shown that vitamin A seems to protect lung cells against 15 Gy X-irradiation (41). All-transretinoic acid, a physiologic metabolite of vitamin A, is able to prevent radiation-induced pulmonary fibrosis when injected intraperitoneally after irradiation (46). Moreover, retinoids protect against injury caused by whole body irradiation (43), radiation injury to the colon (34), and testicular irradiation with incorporated radionuclides (24). The reason for the absence of similar protection in our present studies is not clear.

\section{Clinical Responses}

Our findings are consistent with literature on diminution of vitality and reduced nutritional intake following irradiation (28). Our earlier studies in calorie-restricted mice indicate that acute ( 2 days to $2 \mathrm{wk}$ ) reductions in daily food consumption by up to $30 \%$ have no effect on intestinal nutrient transport (19). Therefore, the observed reductions in intestinal nutrient transport in irradiated mice (Figs. 5-6) can be ascribed mainly to radiation-induced intestinal damage, but not to the reductions in food consumption.

\section{Perspectives and Significance}

The significance of this study stems from the fact that $\sim 0.6$ million cancer patients undergo radiation therapy each year of which over 0.2 million involve the abdominal and pelvic areas. The side effects of radiation on intestinal function dictate the upper limits of radiation therapy. Furthermore, there is increased concern regarding the potential for radiological terrorism and its impact on gastrointestinal function. Here we seek to increase our understanding of the cellular mechanisms underlying intestinal transporter responses to ionizing radiation with the intent of ultimately utilizing our findings not only to develop novel approaches to prevent, ameliorate, and treat radiation-induced gastrointestinal damage but also to increase the tolerance of normal intestinal tissue to improve the quality 
of life of cancer survivors and to enhance radiation efficacy by dose escalation (26).

\section{ACKNOWLEDGMENTS}

The authors thank the staff at the New Jersey Medical School Comparative Resource Facility and the University of Medicine and Dentistry of New Jersey Office of Radiation Services for their dedication and assistance with these studies, Dr. David Lagunoff for assistance with the histology, and Dr. M. Ricci at Research Diets for help in formulating the diets.

\section{GRANTS}

This study was supported, in part, by National Institute of Allergy and Infectious Diseases Grant RC1-AI-078518 (to R. W. Howell). The content is solely the responsibility of the authors and does not necessarily represent the official views of the National Institute of Allergy and Infectious Diseases or the National Institutes of Health. The laboratory of Dr. Ferraris also receives support from National Science Foundation Grant IOS-0722365 and National Institute of Diabetes and Digestive and Kidney Diseases Grant DK-075617A and that of Dr. Howell from National Cancer Institute Grant RO1-CA-83838.

\section{DISCLOSURES}

No conflicts of interest are declared by the author(s).

\section{REFERENCES}

1. Abdelmohsen K, Kuwano Y, Kim HH, Gorospe M. Posttranscriptional gene regulation by RNA-binding proteins during oxidative stress: implications for cellular senescence. Biol Chem 389: 243-255, 2008.

2. Antille C, Tran C, Sorg O, Carraux P, Didierjean L, Saurat JH. Vitamin A exerts a photoprotective action in skin by absorbing ultraviolet B radiation. J Invest Dermatol 121: 1163-1167, 2003.

3. Baer AR, Cheeseman CI, Thomson AB. The assessment of recovery of the intestine after acute radiation injury. Radiat Res 109: 319-329, 1987.

4. Balabanli B, Turkozkan N, Balabanli S, Erdamar H, Akmansu M. The effect of vitamin A pretreatment on radiation induced alteration in neutrophil functions. Mol Cell Biochem 286: 103-105, 2006.

5. Banda M, Bommineni A, Thomas RA, Luckinbill LS, Tucker JD. Evaluation and validation of housekeeping genes in response to ionizing radiation and chemical exposure for normalizing RNA expression in real-time PCR. Mutat Res 649: 126-134, 2008.

6. Becciolini A, Cremonini D, Fabbrica D, Balzi M. Cell proliferation and differentiation in the small intestine after irradiation with multiple fractions. Acta Radiol Oncol 25: 51-56, 1986.

7. Buchwald KW. Influence of X-ray lesions of the intestinal mucosa on absorption of glucose and other sugars. J Exp Med 53: 827-830, 1931.

8. Bullard D, Farrar JT, Ingelfinger FJ, Small MD. Effect of total body irradiation on absorption of sugars from the small intestine. Am J Physiol 186: $549-553,1956$.

9. Burant CF, Takeda J, Brot-Laroche E, Bell GI, Davidson NO. Fructose transporter in human spermatozoa and small intestine is GLUT5. J Biol Chem 267: 14523-14526, 1992.

10. Castello A, Guma A, Sevilla L, Furriols M, Testar X, Palacin M, Zorzano A. Regulation of GLUT5 gene expression in rat intestinal mucosa: regional distribution, circadian rhythm, perinatal development and effect of diabetes. Biochem J 309: 271-277, 1995.

11. Churnratanakul S, Wirzba BJ, Murphy GK, Kirdeikis KL, Keelan M, Clandinin MT, Thomson AB. The irradiation-associated decline in the in vivo uptake of glucose observed in rats fed fish oil is prevented by feeding a diet enriched in saturated fatty acids. J Lab Clin Med 118: 363-369, 1991.

12. Coleman CN, Blakely WF, Fike JR, MacVittie TJ, Metting NF, Mitchell JB, Moulder JE, Preston RJ, Seed TM, Stone HB, Tofilon PJ, Wong RS. Molecular and cellular biology of moderate-dose (1-10 Gy) radiation and potential mechanisms of radiation protection: report of a workshop at Bethesda, Maryland, December 17-18, 2001. Radiat Res 159: 812-834, 2003.

13. Corpe CP, Bovelander FJ, Munoz CM, Hoekstra JH, Simpson IA, Kwon O, Levine M, Burant CF. Cloning and functional characterization of the mouse fructose transporter, GLUT5. Biochim Biophys Acta 1576: 191-197, 2002.

14. Cui XL, Schlesier AM, Fisher EL, Cerqueira C, Ferraris RP. Fructoseinduced increases in neonatal rat intestinal fructose transport involve the
PI3-kinase/Akt signaling pathway. Am J Physiol Gastrointest Liver Physiol 288: G1310-G1320, 2005.

15. Dyer J, Al-Rammahi M, Waterfall L, Salmon KS, Geor RJ, Boure L, Edwards GB, Proudman CJ, Shirazi-Beechey SP. Adaptive response of equine intestinal $\mathrm{Na}^{+}$/glucose co-transporter (SGLT1) to an increase in dietary soluble carbohydrate. Pfügers Arch 458: 419-430, 2009.

16. Dyer J, Wood IS, Palejwala A, Ellis A, Shirazi-Beechey SP. Expression of monosaccharide transporters in intestine of diabetic humans. Am J Physiol Gastrointest Liver Physiol 282: G241-G248, 2002.

17. E X, Zhang L, Lu J, Tso P, Blaner WS, Levin MS, Li E. Increased neonatal mortality in mice lacking cellular retinol-binding protein II. J Biol Chem 277: 36617-36623, 2002.

18. Epperly MW, Osipov AN, Martin I, Kawai KK, Borisenko GG, Tyurina YY, Jefferson M, Bernarding M, Greenberger JS, Kagan VE. Ascorbate as a "redox sensor" and protector against irradiation-induced oxidative stress in 32D CL 3 hematopoietic cells and subclones overexpressing human manganese superoxide dismutase. Int J Radiat Oncol Biol Phys 58: 851-861, 2004.

19. Ferraris RP, Cao QX, Prabhakaram S. Chronic but not acute energy restriction increases intestinal nutrient transport in mice. J Nutr 131: 779-786, 2001.

20. Ferraris RP, Casirola DM, Vinnakota RR. Dietary carbohydrate enhances intestinal sugar transport in diabetic mice. Diabetes 42: 1579 1587, 1993.

21. Francois A, Milliat F, Vozenin-Brotons MC, Mathe D, Griffiths NM. "In-field" and "out-of-field" functional impairment during subacute and chronic phases of experimental radiation enteropathy in the rat. Int $J$ Radiat Biol 79: 437-450, 2003.

22. Gelain DP, de Bittencourt Pasquali MA, Caregnato FF, Zanotto-Filho A, Moreira JC. Retinol up-regulates the receptor for advanced glycation endproducts (RAGE) by increasing intracellular reactive species. Toxicol In Vitro 22: 1123-1127, 2008.

23. Gelain DP, de Bittencourt Pasquali MA, Zanotto-Filho A, de Souza LF, de Oliveira RB, Klamt F, Moreira JC. Retinol increases catalase activity and protein content by a reactive species-dependent mechanism in Sertoli cells. Chem Biol Interact 174: 38-43, 2008.

24. Harapanhalli RS, Narra VR, Yaghmai V, Azure MT, Goddu SM, Howell RW, Rao DV. Vitamins as radioprotectors in vivo. II. Protection by vitamin A and soybean oil against radiation damage caused by internal radionuclides. Radiat Res 139: 115-122, 1994.

25. Haton C, Francois A, Vandamme M, Wysocki J, Griffiths NM, Benderitter M. Imbalance of the antioxidant network of mouse small intestinal mucosa after radiation exposure. Radiat Res 167: 445-453, 2007.

26. Haydont V, Bourgier C, Vozenin-Brotons MC. Rho/ROCK pathway as a molecular target for modulation of intestinal radiation-induced toxicity. Br J Radiol 80, Spec No 1: S32-S40, 2007.

27. Hirayama BA, Loo DD, Diez-Sampedro A, Leung DW, Meinild AK, Lai-Bing M, Turk E, Wright EM. Sodium-dependent reorganization of the sugar-binding site of SGLT1. Biochemistry 46: 13391-13406, 2007.

28. Jagetia GC, Baliga MS. Polyherbal extract of septilin protects mice against whole body lethal dose of gamma radiation. Phytother Res 18: 619-623, 2004.

29. Jiang L, Ferraris RP. Developmental reprogramming of rat GLUT-5 requires de novo mRNA and protein synthesis. Am J Physiol Gastrointest Liver Physiol 280: G113-G120, 2001.

30. Karasov WH, Diamond JM. A simple method for measuring intestinal solute uptake in vitro. J Comp Physiol 152: 105-116, 1983.

31. Karasov WH, Pond RS 3rd, Solberg DH, Diamond JM. Regulation of proline and glucose transport in mouse intestine by dietary substrate levels. Proc Natl Acad Sci USA 80: 7674-7677, 1983.

32. Kirchner S, Muduli A, Casirola D, Prum K, Douard V, Ferraris RP. Luminal fructose inhibits rat intestinal sodium-phosphate cotransporter gene expression and phosphate uptake. Am J Clin Nutr 87: 1028-1038, 2008.

33. Letschert JG. The prevention of radiation-induced small bowel complications. Eur J Cancer 31A: 1361-1365, 1995.

34. Mason KA, Tofilon PJ. Unexpected radiation protection with 13-cisretinoic acid plus interferon $\alpha-2 \mathrm{a}$. Cancer Chemother Pharmacol 33: 435-437, 1994.

35. Miholic J, Vogelsang H, Schlappack O, Kletter K, Szepesi T, Moeschl P. Small bowel function after surgery for chronic radiation enteritis. Digestion 42: 30-38, 1989. 
36. Moore MJ, Proudfoot NJ. Pre-mRNA processing reaches back to transcription and ahead to translation. Cell 136: 688-700, 2009.

37. Neti PV, de Toledo SM, Perumal V, Azzam EI, Howell RW. A multi-port low-fluence $\alpha$-particle irradiator: fabrication, testing and benchmark radiobiological studies. Radiat Res 161: 732-738, 2004.

38. Neti PV, Howell RW. Isolating effects of microscopic nonuniform distributions of ${ }^{131} \mathrm{I}$ on labeled and unlabeled cells. J Nucl Med 45: 1050-1058, 2004.

39. Overgaard J, Matsui M. Effect of radiation on glucose absorption in the mouse jejunum in vivo. Radiother Oncol 18: 71-77, 1990.

40. Peluso I, Campolongo P, Valeri P, Romanelli L, Palmery M. Intestinal motility disorder induced by free radicals: a new model mimicking oxidative stress in gut. Pharmacol Res 46: 533-538, 2002.

41. Redlich CA, Rockwell S, Chung JS, Sikora AG, Kelley M, Mayne ST. Vitamin A inhibits radiation-induced pneumonitis in rats. J Nutr 128: 1661-1664, 1998.

42. Rigtrup KM, Ong DE. A retinyl ester hydrolase activity intrinsic to the brush border membrane of rat small intestine. Biochemistry 31: 29202926, 1992.

43. Seifter E, Rettura G, Padawer J, Stratford F, Weinzweig J, Demetriou AA, Levenson SM. Morbidity and mortality reduction by supplemental vitamin $\mathrm{A}$ or $\beta$-carotene in CBA mice given total-body gamma-radiation. J Natl Cancer Inst 73: 1167-1177, 1984.
44. Solberg DH, Diamond JM. Comparison of different dietary sugars as inducers of intestinal sugar transporters. Am J Physiol Gastrointest Liver Physiol 252: G574-G584, 1987.

45. Sommer A. Vitamin A deficiency and clinical disease: an historical overview. J Nutr 138: 1835-1839, 2008.

46. Tabata C, Kadokawa Y, Tabata R, Takahashi M, Okoshi K, Sakai Y, Mishima M, Kubo H. All-trans-retinoic acid prevents radiation- or bleomycin-induced pulmonary fibrosis. Am J Respir Crit Care Med 174: 1352-1360, 2006.

47. Thomas S, Prabhu R, Balasubramanian KA. Retinoid metabolism in the rat small intestine. Br J Nutr 93: 59-63, 2005.

48. Thomson AB, Cheeseman CI, Walker K. Late effects of abdominal radiation on intestinal uptake of nutrients. Radiat Res 107: 344-353, 1986.

49. Thomson AB, Keelan M, Cheeseman CI, Walker K. Fractionated low doses of abdominal irradiation alters jejunal uptake of nutrients. Int $J$ Radiat Oncol Biol Phys 12: 917-925, 1986.

50. Walsh D. Deep tissue traumatism from roentgen ray exposure. $\mathrm{Br}$ Med J 2: 272-275, 1897

51. Weiss JF, Landauer MR. Protection against ionizing radiation by antioxidant nutrients and phytochemicals. Toxicology 189: 1-20, 2003.

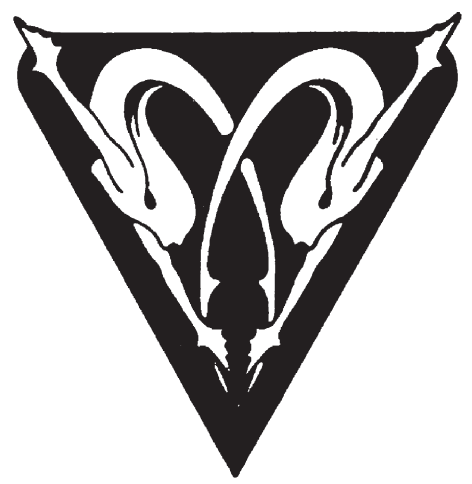

